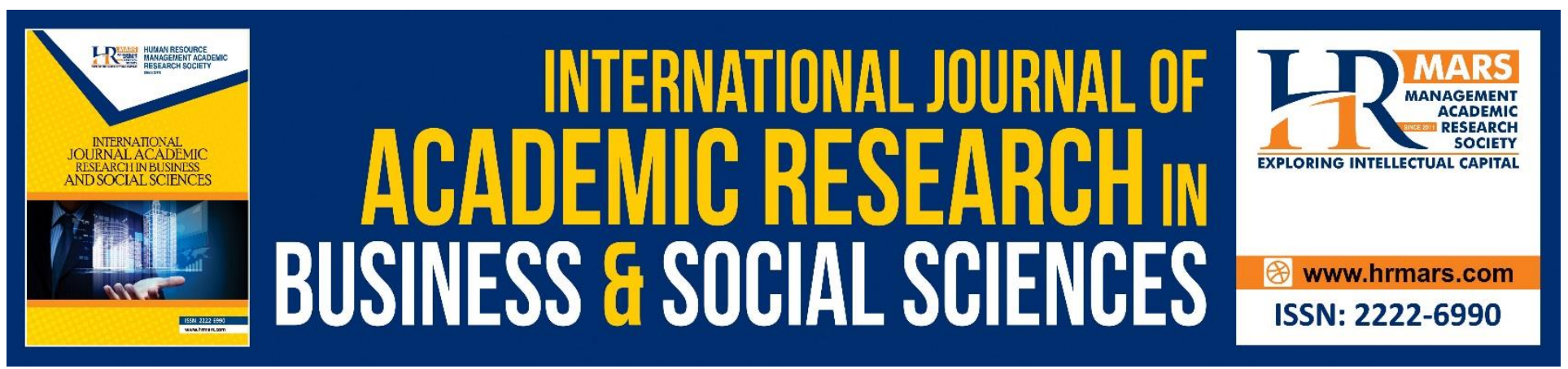

\title{
ACTIVE LEARNING: Activities and practices in Islamic Subjects
}

\section{Azlina Mustaffa}

To Link this Article: http://dx.doi.org/10.6007/IJARBSS/v8-i12/5411

DOI: $10.6007 /$ IJARBSS/v8-i12/5411

Received: 30 Nov 2018, Revised: 23 Dec 2018, Accepted: 28 Dec 2018

Published Online: 06 Jan 2019

In-Text Citation: (Mustaffa, 2018)

To Cite this Article: Mustaffa, A. (2018). ACTIVE LEARNING: Activities and practices in Islamic Subjects. International Journal of Academic Research in Business and Social Sciences, 8(12), 2121-2127.

\section{Copyright: (C) 2018 The Author(s)}

Published by Human Resource Management Academic Research Society (www.hrmars.com)

This article is published under the Creative Commons Attribution (CC BY 4.0) license. Anyone may reproduce, distribute, translate and create derivative works of this article (for both commercial and non-commercial purposes), subject to full attribution to the original publication and authors. The full terms of this license may be seen

at: $\underline{\text { http://creativecommons.org/licences/by/4.0/legalcode }}$

Vol. 8, No. 12, 2018, Pg. 2121 - 2127

http://hrmars.com/index.php/pages/detail/IJARBSS

JOURNAL HOMEPAGE

Full Terms \& Conditions of access and use can be found at http://hrmars.com/index.php/pages/detail/publication-ethics 


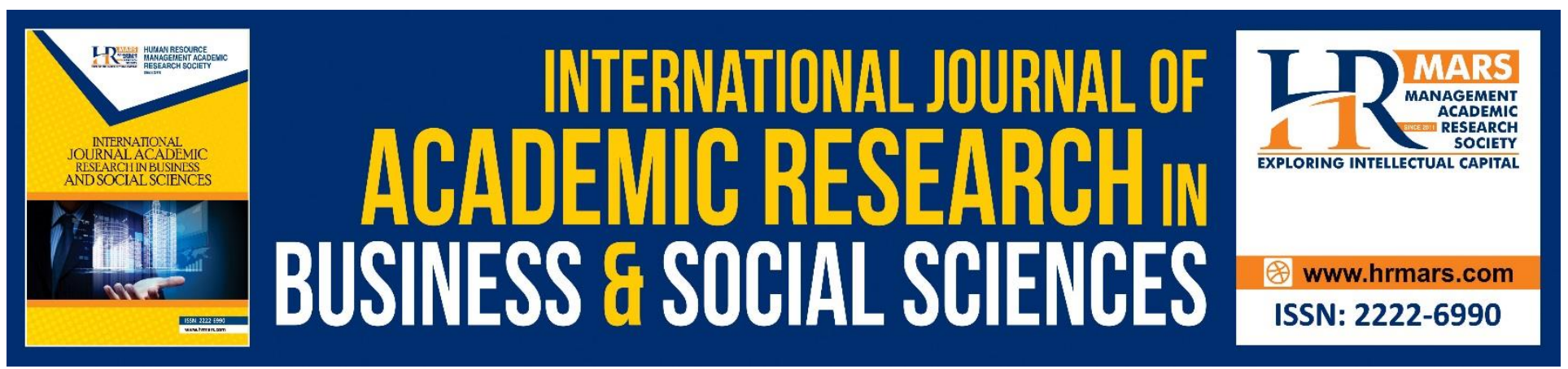

\title{
ACTIVE LEARNING: Activities and practices in Islamic Subjects
}

\author{
Azlina Mustaffa \\ Kulliyyah of Education, International Islamic University Malaysia \\ Email: azlina910@yahoo.com
}

\begin{abstract}
This paper reviews the connection between active learning activities and practices in Islamic subjects. Active learning has been shown more effective for students to learn, yet there is concern that some students prefer active learning approaches compared than passive listeners. The paper analyses and proposes the different ways to Islamic Education teachers in secondary schools to practices active learning. The paper finds five suitable ways that activities in active learning applicable in Islamic subjects.
\end{abstract}

Keywords: Active Learning, Islamic Education, Secondary Schools, Teachers, Practices

\section{Introduction}

Education is the main and important agenda in human life. It can help many people to develop and acquired knowledge, skills, values and attitudes from meaningful and beneficial (Tesfaye \& Berhanu, 2015). In Islamic subjects for example, this subjects contains of many verses and hadiths which is required to memorizing. In fact, Islamic subjects not only memorizing, but understanding and practically to do it. Learning is not totally memorizing in Islam, but, in order to understand and gain knowledge, students' needs to solve problems, share the ideas and explore and discover new things by themselves with the guidance by their teacher (Yusuf \& Wekke, 2015).

In Malaysia education systems, Islamic education is regarded as the core in the curriculum education systems based on the religious substances, supported by Islamic methodologies and learning methods (A. H. Tamuri, 2015). Using the active learning in Islamic subjects actually not new. The term is widely used among teachers but, still less practices in Islamic subjects. Some western countries, in UK, for example, Northern education system policy put 'active learning and teaching methods' at the centre of the curriculum (Drew \& Mackie, 2011). Even though the policy has been highlighted in Malaysian Education Blueprint which is the shift 1 to develop students successful and balanced person, there are missing in teaching methods in active learning especially among teachers in schools. 


\section{Activities of Active Learning}

There are many activities in active learning. Some studies conducted by Bonwell \& Eison, 1991; Brame, 2016 observed that the activities in active learning can be categorized into two group, which are higher risk activities and lower risk activities. Bonwell \& Eison, (1991) point out that guided lectures, presentations, pair or group write test, and problem analysis are included in the higher risk activities, meanwhile the lower risk activities include short writing, reading, thumbs up or down response to statements, quizzes, think-pair-share, and brainstorming.

However, these activities emphasize that every student is encouraged to talk and listen, write and read, as well think and write. It supported the approaches by Bloom Taxonomy whereby the activities such as think-pair-share requires higher order thinking skills in the stages of application, analysis, or evaluation. Bloom's (1956) who proposed the Taxonomy of learning that identified the three domains of cognitive, affective and psychomotor learning. It emphasized-on students' skills or transmitting information through their own attitude, intrinsic values, and extrinsic motivation (Drew \& Mackie, 2011; Krathwohl, 2016; Kudryashova, Gorbatova, Rybushkina, \& Ivanova, 2015; Pundak, Herscovitz, Shacham, \& Wiser-Biton, 2009).

It has been shown that the opportunities that students' experiences reflect the idea, content, and issue related to academic and real-life situations. Figure 2.3 below shows the revised Taxonomy Bloom in active learning when it is applied in the classroom (Krathwohl, 2016).

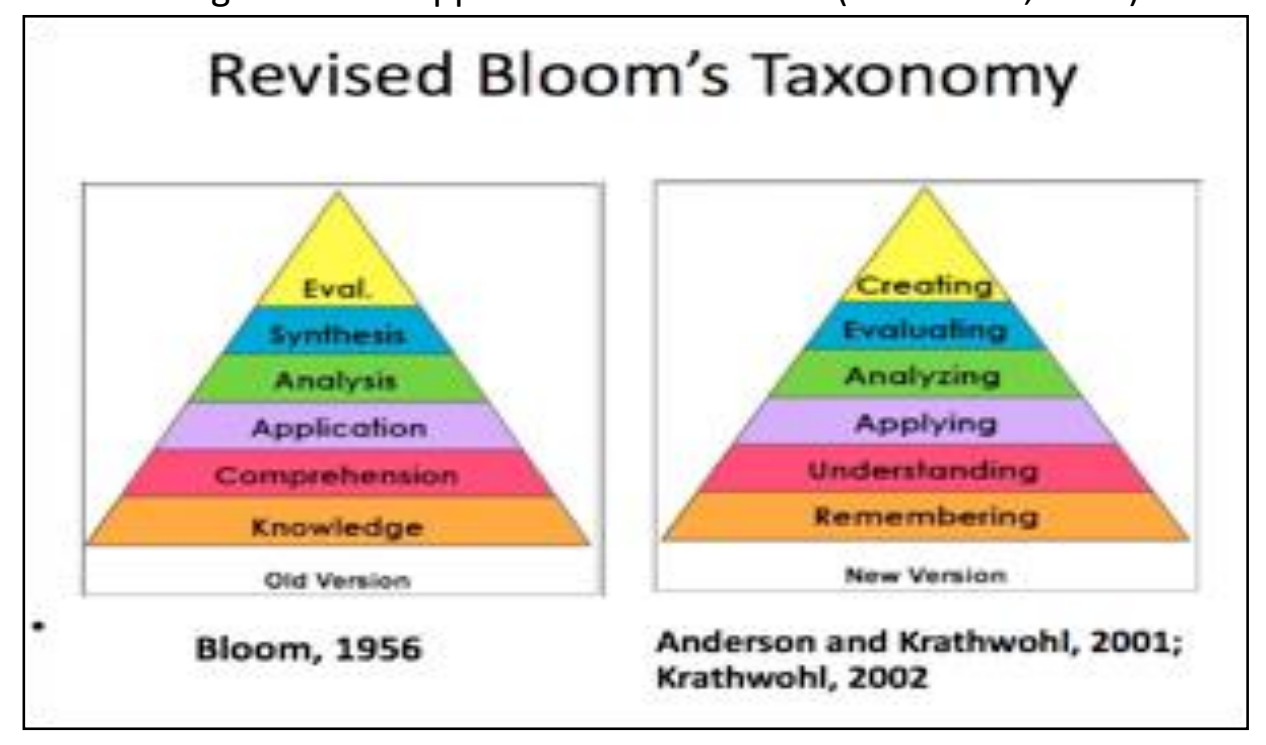

Figure Error! No text of specified style in document..1 Revised Bloom's Taxonomy process in active learning.

Source from (Krathwohl, 2016).

\section{Collaborative Learning}

These activities are involved in smaller group with 2 to 5 members in each group. Each group must complete the task given by the teachers. After they complete the task, the students are evaluated on group or peer basis (Benjamin, 2015). According to Belcadhi \& Ghannouchi, (2014) the examples of active learning methods include problem-based learning, case studies, projects, 
simulations, and technology uses. These methods encourage students' engagement with critical thinking, analysis, synthesis, and evaluation of information.

The process to integrate lecture and collaborative or cooperative learning occur in 10 to 15 minutes each part in a large class. After that, students are exposed to two or three activities in large or small groups, pairs, or case studies (Adkins, 2017).

There are studies on the integrating of active learning and speaking class that indicated that collaborative learning give positive correlation between group engagement and the quality of cognitive skills of the students (Pundak et al., 2009; Rochmahwati, 2013).

Thus, collaborative learning can be applied in Islamic Education subject by conducting activities such as dealing and arguing certain issues or topics, involving problem solving skills, and promote critical thinking. Usually, teachers in Islamic Education area apply these strategies in the sub-topics under the adab subject.

\section{Demonstration}

In the teaching of Islamic Education, the activities using demonstration always focus on the topic of Ibadah. The topic that is generally needed demonstration on how to take wudhu, tayammum, how to perform solat, or the cleanliness of najis muhaffah, mutawasitah, and mughalazah. Students understand better when the activities is hands-on and involve the process of inquiry, discovery, investigation, and interpretation (Tesfaye \& Berhanu, 2015). The study conducted by (A. B. H. Tamuri, Khairul, \& Ajuhary, 2010) shows that demonstration is commonly used by teachers during teaching and learning sessions. It is also supported by (Jasmi \& Tamuri, 2011), pointing that most Islamic Education teachers usually use the same techniques which are questionnaire, recitation of verses, group discussions, memorizing individually, and memorizing in groups.

Demonstration is the most significant type of the many activities in active learning. However, in the case of Madda Walabu University Bale, Robe, Uthophia, majority of the students stated that the biggest challenge to be involved in any discussion, demonstration, and presentation, is the poor academic background, shyness in communication skills, and previous negative classroom experiences (Tesfaye \& Berhanu, 2015) .

\section{Story Telling}

Story telling is also one of the techniques suitable in teaching Islamic Education particularly in the sub-topic of sirah and akhlaq. It concentrated on the way, why and how our prophets (PBUH) and Allah describe the story from the Quran and sunnah. For instance, in the new syllabus in KSSM, the topic is related to stories of companions and so on.

The challenges are the knowledge and implementation of the Islamic Education teachers are depending on the textbook. In fact, the students already read and know the story until the end. The consequence is that the classes will not be interesting enough because the students already know the story. They want new things. Jasmi \& Tamuri, (2011) explored the practicality of teaching aids in Islamic Education Subject and found that most of the excellent teachers in the urban areas uses the story telling method. 
INTERNATIONAL JOURNAL OF ACADEMIC RESEARCH IN BUSINESS AND SOCIAL SCIENCES

Vol. 8, No. 12, Dec, 2018, E-ISSN: $2222-6990$ C 2018 HRMARS

Because of that, Islamic Education teachers should maintain the concept of acquiring knowledge in order to maximize the effort to make the students motivated and love to become a part of a successful ummah.

\section{Question and Answer}

This technique is a must in any subject to ensure the understanding of any certain topic. By asking questions, teachers will know the problems, conflicts, and the level of understanding for that particular subject. The concept is also synonymous with forming question activities, think-pare-share activities, one-minute paper, and many more (Brame, 2016). Teachers leads or directs the questions in the induction set, explanations, activities, and conclusion. However, there are many studies, locally and internationally, indicating that lecture method and memorizing are frequent methods when teachers teach Islamic Education. This leads to passive learning among students (Halim Tamuri, 2007; Hussin, Noh, \& Tamuri, 2014; Maimun, Wan Nurul Syuhada', \& Mohd Isa, 2017).

Another study conducted by Riley \& Ward, (2017) reported the evidence that active learning improve students outcomes greater than the cooperative learning or passive learning methods. The results indicated that students in the active learning class reveals the highest exam score, respond positively, and more satisfaction compared to students in the traditional lecture where the results indicated that no significant improvement in exams (Hyun, Ediger, \& Lee, 2017).

\section{Brainstorming}

Brainstorming is the activity that involves predicting, recalling, relating, connecting, and problem solving to get ideas. In the teaching of Islamic Education, the technique is frequently seen to be used in the more excellent classes. Regardless of the students' excellence, moderate, or poor academic performance, a study was conducted in the physical sports area for example. The volleyball beginners started with brainstorming ideas seven weeks before they implemented the programme (Saleh \& Ibnian, 2011). The results indicated that the method of brainstorming demonstrated a positive effect on learning the skills of passing, serve, and smash stroke.

\section{Conclusion}

This study suggests the activities to the teachers to implement the active learning. After reviewing some of the literature, these five activities hopefully will increase students' participation in learning Islamic Education.

\section{References}

Adkins, J. K. (2017). Active Learning and Formative Assessment in a User-Centered Design Course, 1-7.

Belcadhi, L. C., \& Ghannouchi, S. A. (2014). Conceptual Design and Validation of Meta-Model for Active e-Learning. International Journal of Information and Education Technology, 4(1), 42-48. https://doi.org/10.7763/IJIET.2014.V4.366

Benjamin, C. (2015). by.

Bonwell, C. C., \& Eison, J. A. (1991). Active Learning : Creating Excitement in the Classroom. Learning, 80819(719), 1-6. https://doi.org/ED340272 
INTERNATIONAL JOURNAL OF ACADEMIC RESEARCH IN BUSINESS AND SOCIAL SCIENCES

Vol. 8, No. 12, Dec, 2018, E-ISSN: 2222-6990 @ 2018 HRMARS

Brame, C. (2016). Active Learning. Vanderbilt University Center for Teaching. https://doi.org/10.2200/S00429ED1V01Y201207AIM018

Drew, V., \& Mackie, L. (2011). Extending the constructs of active learning: Implications for teachers' pedagogy and practice. Curriculum Journal, 22(4), 451-467. https://doi.org/10.1080/09585176.2011.627204

Halim Tamuri, A. (2007). Islamic Education teachers' perceptions of the teaching of akhlāq in Malaysian secondary schools. Journal of Moral Education, 36(3), 371-386. https://doi.org/10.1080/03057240701553347

Hussin, N. H., Noh, M. A. C., \& Tamuri, A. H. (2014). The Religious Practices Teaching Pedagogy of Islamic Education Excellent Teachers. Mediterranean Journal of Social Sciences, 5(16), 239246. https://doi.org/10.5901/mjss.2014.v5n16p239

Hyun, J., Ediger, R., \& Lee, D. (2017). Students ' Satisfaction on Their Learning Process in Active Learning and Traditional Classrooms. International Journal of Teaching and Learning in Higher Education, 29(1), 108-118. Retrieved from http://www.isetl.org/ijtlhe/

Jasmi, K. A., \& Tamuri, A. H. (2011). Amalan Penggunaan Bahan Bantu Mengajar dalam Kalangan Guru Cemerlang Pendidikan Islam Sekolah Menengah di Malaysia. Journal of Islamic and Arabic Education 3(1), 3(1), 59-74.

Krathwohl, A. and. (2016). Anderson and Krathwohl - Bloom 's Taxonomy Revised Understanding the New Version of Bloom 's Taxonomy, (1972).

Kudryashova, A., Gorbatova, T., Rybushkina, S., \& Ivanova, E. (2015). Teacher's Roles to Facilitate Active Learning. Mediterranean Journal of Social Sciences, (December 2015). https://doi.org/10.5901/mjss.2016.v7n1p460

Maimun, A. L., Wan Nurul Syuhada', W. H., \& Mohd Isa, H. (2017). Tahap pengetahuan dan kesediaan guru-guru pendidikan islam sekolah menengah di selangor terhadap penggunaan multimedia dalam pengajaran pendidikan Islam. ASEAN Comparative Education Research Journal on Islam and Civilization, 1(January), 1-13. Retrieved from http://spaj.ukm.my/acerj/index.php/acer-j/article/view/3/3

Pundak, D., Herscovitz, O., Shacham, M., \& Wiser-Biton, R. (2009). Instructors' attitudes toward active learning. Interdisciplinary Journal of Knowledge and Learning Objects, 5, 215-235. Retrieved from http://ijklo.org/Volume5/IJELLOv5p215-232Pundak669.pdf?q=instructors

Riley, J., \& Ward, K. (2017). Active learning, cooperative active learning, and passive learning methods in an accounting information systems course. Issues in Accounting Education, 32(2), 1-16. https://doi.org/10.2308/iace-51366

Rochmahwati, P. (2013). INTEGRATING ACTIVE LEARNING IN A COOLEGE SPEAKING CLASS. Journal on English as a Foreign Language, 3(1), 31-40.

Saleh, S., \& Ibnian, K. (2011). Brainstorming and Essay Writing in EFL Class. Theory and Practice in Language Studies, 1(3), 263-272. https://doi.org/10.4304/tpls.1.3.263-272

Tamuri, A. B. H., Khairul, M., \& Ajuhary, A. (2010). Amalan Pengajaran Guru Pendidikan Islam Berkesan Berteraskan Konsep Mu ' allim. Journal of Islamic and Arabic Education, 2(1), 43-56.

Tamuri, A. H. (2015). Standardization of Islamic Education Excellence in The World, 1(2).

Tesfaye, S., \& Berhanu, K. (2015). Improving Students' Participation in Active Learning Methods: Group Discussions, Presentations and Demonstrations: A Case of Madda Walabu University 
INTERNATIONAL JOURNAL OF ACADEMIC RESEARCH IN BUSINESS AND SOCIAL SCIENCES

Vol. 8, No. 12, Dec, 2018, E-ISSN: 2222-6990 @ 2018 HRMARS

Second Year Tourism Management Students of 2014. Journal of Education and Practice, 6(22), 29-32. Retrieved from

https://search.ebscohost.com/login.aspx?direct=true\&db=eric\&AN=EJ1079478\&site=ehostlive

Yusuf, M., \& Wekke, I. S. (2015). Active Learning on Teaching Arabic for Special Purpose in Indonesian Pesantren. Procedia - Social and Behavioral Sciences, 191, 137-141.

https://doi.org/10.1016/j.sbspro.2015.04.245 